\title{
"MONEY MATTERS"; DIVIDING BUSINESS INTERESTS ON DIVORCE OR DISSOLUTION: SPECIAL REFERENCE TO THE BUSINESS ENTITIES
}

\author{
Norliah binti Ibrahim * \\ Zuhairah Ariff binti Abdul Ghadas ** \\ Roslina Che Soh ${ }^{* * *}$
}

\begin{abstract}
In Malaysia, the contribution test is applied by both the civil and Syariah courts to determine claims in business interest as matrimonial property. However, it is observed that different from claims on interest in personal property, the courts need to apply an additional test other than the contribution test in determining claims of matrimonial property in business interest. This is because the ownership structure in business are different from ownership of personal property and highly dependents on types of the business entities. Apart from analyzing the approaches adopted in the Malaysian courts in dividing business interest upon divorce or dissolution of marriage, this research also highlights the arising legal issues which may arise in respect of different business entities in which the business interest exists. This study was conducted primarily through a doctrinal study of existing literature such as articles, journals and the decision from the relevant case laws which was decided in both the Civil and Shariah courts. This research found that other than types of business entities, the interest of parties in business is also determined by the quantum of shareholding or contribution in the business.
\end{abstract}

Keywords: matrimonial property, business interest, business entities, Shariah, company.

* Associate Professor at Ahmad Ibrahim of Laws, International Islamic University Malaysia. Email: norliah@iium.edu.my.

** Professor of Law, University Sultan Zainal Abidin. Email: zuhairahariff@unisza.edu.my.

*** Associate Professor at Ahmad Ibrahim of Laws, International Islamic University Malaysia. Email: roslinac@iium.edu.my. 


\title{
"ISU KEWANGAN" PEMBAHAGIAN KEPENTINGAN \\ PERNIAGAAN APABILA BERLAKUNYA PERCERAIAN DAN \\ PEMBUBARAN: RUJUKAN KHAS KEPADA ENTITI \\ PERNIAGAAN
}

\begin{abstract}
ABSTRAK
Di Malaysia, ujian sumbangan dilaksanakan oleh mahkamah Sivil dan Shariah untuk menentukan tuntutan kepentingan perniagaan sebagai harta perkahwinan. Namun, didapati bahawa berbeza dengan tuntutan kepentingan harta benda peribadi, mahkamah harus menerapkan ujian tambahan selain ujian sumbangan dalam menentukan tuntutan harta perkahwinan yang terdapat padanya faedah perniagaan. Ini kerana struktur pemilikan dalam perniagaan berbeza dengan pemilikan harta peribadi dimana ia bergantung pada jenis entiti perniagaan itu sendiri. Selain menganalisis pendekatan yang terpakai di Mahkamah-Mahkamh di Malaysia dalam membagi kepentingan perniagaan setelah perceraian atau pembubaran perkahwinan, kajian ini juga mengkaji permasalahan yang mungkin akan timbul berkaitan dengan entiti perniagaan yang berlainan di mana kepentingan perniagaan itu wujud. Kajian ini adalah kajian penyelidikan undang-undang secara doktrinal keatas literatur sedia ada seperti artikel, jurnal dan keputusan kes-kes berkaitan yang telah diputuskan di Mahkamah Sivil dan Shariah. Penyelidikan ini mendapati bahawa selain jenis entiti perniagaan, kepentingan pihak dalam perniagaan juga ditentukan oleh jumlah pegangan saham atau sumbangan dalam perniagaan itu sendiri.
\end{abstract}

Kata kunci: harta perkahwinan, kepentingan perniagaan, entiti perniagaan, Syariah, syarikat.

\section{INTRODUCTION}

In Malaysia, both the civil and Syariah courts generally apply the "contribution test" in deciding rights and proportion of the divorced parties in claims of matrimonial property. It is observed that the contribution test could be effectively be applied for tangible property such as houses, land, vehicles and savings, which are personally owned by the parties. However, when it comes to assets under a business's name, which is owned, by both or one of the parties, the contribution test may not be appropriate. This is because the parties' interest in the business is indirect and shall be subjected to the type of business structure and nature of the person's interest in the business. For 
example, a person who holds majority or all shares in a company does not have interest in the company's property, although it is in the possession or used by the owner. In short, when it comes to distribution of assets in a business as matrimonial property, the contribution test is seen to be insufficient to be the sole test for the court to apply. This article aims to discuss approaches of both the civil and Syariah courts in deciding claims of divorced parties in business interest as matrimonial property. This analysis is important to identify the differences and similarities of legal principles or test applied by the two courts in determining claims of assets other than personal property. With the vast development in e-business, such findings are pertinent to assist the courts in determining matrimonial property existence and the amount of interest involved.

\section{THE LAW ON MATRIMONIAL PROPERTY IN MALAYSIA}

In Malaysia, the law that governs the division of matrimonial property is the Law Reform (Marriage and Divorce) Act 1976 (hereinafter referred to as the LRA). As its long title provides that it is an Act to provide for monogamous marriages and the solemnization and registration of such marriages and to amend and consolidate the law relating to divorce and to provide for matters incidental thereto, the division of matrimonial property is specifically dealt with in section 76 of the Act. The Act which generally applies not only to all persons in Malaysia but also to those residents outside Malaysia whose domicile is in Malaysia ${ }^{1}$ was enforced throughout Malaysia since the date of the enforcement of the LRA i.e., first March 1982. ${ }^{2}$

Meanwhile, Muslims are governed by the Islamic Family Law Act and Enactments. However, for the purpose of this article, reference is made only to the Malaysian law as codified in the Islamic Family Law (Federal Territories) Act 1984, (hereinafter referred to as the IFLA) which is also the model followed by many other states in Malaysia.

2 See PU (B) 73/1982. 


\section{LAW REFORM (MARRIAGE AND DIVORCE) ACT 1976}

Section 76 reads:

(1) The court shall have power when granting a decree of divorce or judicial separation, to order the division between the parties of any assets acquired by them during the marriage or the sale of any such assets and the division between the parties of the proceeds of sale.

(2) In exercising the power conferred by subsection (1), the court shall have regard to-

(a) the extent of the contributions made by each party in money, property or work towards the acquiring of the assets or payment of expenses for the benefit of the family;

(aa) the extent of the contributions made by the other party who did not acquire the assets to the welfare of the family by looking after the home or caring for the family;

(b) any debts owing by either party which were contracted for their joint benefit;

(c) the needs of the minor children, if any, of the marriage;

(d) the duration of the marriage,

and subject to those considerations, the court shall incline towards the equality of division.

(3) (Deleted)

(4) (Deleted).

(5) For the purposes of this section, references to assets acquired during marriage include assets owned before the marriage by one party, which have been substantially improved during the marriage by the other party or by their joint efforts."

Referring to the above provision, it is clear that section 76 of the LRA is dealing with the power of the

The Court is to order a division of matrimonial assets acquired during the marriage upon granting a decree of divorce or judicial separation. In exercising the power conferred by this section, the court shall incline towards equality of division. However, there are certain factors that the court will take into consideration including the extent 
of contributions made by each party in money, property or work towards the acquiring the assets or payment of expenses for the benefit of the family, the extent of the contributions made by the other party who did not acquire the assets to the welfare of the family by looking after the home or caring for the family, any debts owing by either party which were contracted for their joint benefit, the needs of the minor children, if any, of the marriage and the duration of the marriage. Aliza Sulaiman, JC in deciding the case of Poonageswari a/p P. Krishnan $v$ Bailand a/l Govindanam ${ }^{3}$ commented that the objective of the provision is to provide better security to the positions of wives and to give due recognition to their contribution in kind of taking care of the home and the members. In some cases, some who may even had to give up their salaried employment and whatever career advancements or opportunities they had in order to take care of the family. In other words, the sacrifices made by the fairer sex for the well-being of the family, especially the nuclear family unit, are not in vain. ${ }^{4}$

Additionally, section 76(5) of the LRA further elaborates that for the purpose of this section, assets acquired during a marriage includes assets owned before the marriage by one party. Nevertheless, it is subject to the condition that the claimed property must be substantially improved during the marriage by the other party or by their joint effort. This condition has been demonstrated in the case of $L C Y v T W Y^{5}$ where the court emphasized that although the matrimonial home was owned by the husband before their marriage, it has been substantially improved by the wife by renovating the house before they moved in. Thus, the court ordered that the matrimonial home be sold or disposed at the prevailing market value and the net proceeds be divided equally between the parties. Or alternatively, either party may elect to buy out the other undivided share $(50 \%)$ in the said property at the prevailing market value. ${ }^{6}$

[2019] MLJU 448

Ibid, at p. 458.

[2019] 4 MLJ 203.

Ibid, at p. 6 . 


\section{ISLAMIC FAMILY LAW (FEDERAL TERRITORIES) ACT 1984}

Section 122 reads: -

(1) The court shall have power, when permitting the pronouncement of talaq or when making an order of divorce, to order the division between the parties of any assets acquired by them during the marriage by their joint efforts or the sale of any such assets and the division between the parties any proceeds of sale.

(2) In exercising the power conferred by sub-section (1) the court shall have regard to-

(a) the extent of contributions made by each party in money, property or labour towards the acquiring the assets;

(b) any debts owing by either party that were contracted for their joint benefit; and

(c) the needs of the minor children (if any) of the marriage, and subject to those considerations, the court shall incline towards equality of division.

(3) The Court shall have power, when permitting the pronouncement of talaq or when making an order of to order the division between the parties of any assets acquired by them during the marriage by the sole efforts of one part to the marriage or the sale of any such assets and the division between the parties any proceeds of sale.

(4) In exercising the power conferred by sub-section (1) the court shall have regard to-

(a) the extent of the contributions made by the other party who did not acquire the assets to the welfare of the family by looking after the home or caring the family;

(b) the needs of the minor children, if any, of the marriage;

and subject to those considerations, the court may divide the assets or the proceeds of sale in such proportions as the courts think reasonable; but in any case, the party by whose effort the assets were acquired will get a greater proportion.

(5) For the purposes of this section, references to assets acquired during marriage include assets owned before the marriage by one party, which have been substantially improved during the marriage by the other party or by their joint efforts." 
The section is divided into two parts; one is where the assets were acquired by joint effort which is provided for in sub section (1) and the other where they were acquired by the sole effort of one party to the marriage which is dealt with in sub section (3). For the first category, the court shall lean towards equality of division, subject however, to certain factors for consideration such as the extent of the contribution made by each party in money, property or work towards the acquiring of the assets. ${ }^{7}$ Besides, any debts owing by either party which were contracted for their joint benefit will also be considered without undermining the needs of the minor children, if any, of the marriage. ${ }^{8}$

For assets acquired by the sole effort of one party to the marriage, the court may divide the assets in such proportions as it thinks reasonable. ${ }^{9}$ However this is also subject to certain factors namely the extent of the contribution made by the other party who did not acquire the assets to the welfare of the family by looking after the home or caring for the family. ${ }^{10}$ Similarly, if there are minor children from the marriage, their needs shall be taken into consideration as provided for in section 122(4) (b) of the IFLA. Provided, however, that in any case the party by whose efforts were acquired shall receive a greater proportion. ${ }^{11}$

In the case of Azizah bt MudaVMohd Kamal@Raja Kumaran bin Abdullah ${ }^{12}$ the court in declaring the house and a car as matrimonial property has emphasized that contribution is divided into two ie direct and indirect contribution. The court also highlighted that to determine the apportionment of a property which is declared as matrimonial property, the court must scrutinize and determine the contribution of both parties towards the property in order not to oppress to the extent of handling something to the undeserving. ${ }^{13}$ The same arguments has also been stressed by the Court in allowing the appeal made by the appellant wife in the case of Muhmmad Ali bin Abdul Kadir lwn Susaila Avaiar bin Abdullah. ${ }^{14}$ In this case, the court

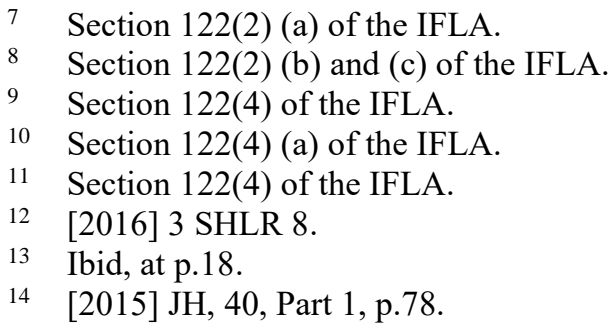

Section 122(2) (a) of the IFLA.

Section 122(2) (b) and (c) of the IFLA.

Section 122(4) of the IFLA.

Section 122(4) (a) of the IFLA.

Section 122(4) of the IFLA.

[2016] 3 SHLR 8.

Ibid, at p.18.

14 [2015] JH, 40, Part 1, p.78. 
emphasized that delivering and taking care of their six children from the marriage without assisted by a helper was regarded as her indirect contribution to the acquisition of the property. ${ }^{15}$

Hence, section 122(5) of the IFLA is similar to the section 76(5) of the LRA which further elaborates that for the purpose of this section, assets acquired during a marriage includes assets owned before the marriage by one party as well. Nevertheless, it is subject to the condition that the claimed property must be substantially improved during the marriage by the other party or by their joint effort.

\section{LEGAL STATUS OF BUSINESS ENTITIES IN MATRIMONIAL PROPERTY IN MALAYSIA}

In Malaysia, there are four types of business entities, which can be formed to carry out business:

- Sole proprietorship

- Partnership

- Company

- $\quad$ Limited Liability Partnerships

Among these business entities, only a company and a limited liability partnership are recognized as legal entities whilst the sole proprietorship and partnership are not recognized as legal entities. The legal status of the business entities is the most important attribute, which affect rights of the owners in the businesses.

\section{i) Sole Proprietorships}

This is the most basic business entity, which are available in the market place. Sole proprietorship is also known as sole trader. It is formed, managed and owned by one person, i.e. the owner or proprietor. This entity is not formally regulated as the transactions entered by this entity are based on contractual principles. Sole proprietorship is not recognized by the law as a legal entity. There is no legal distinction between the owner and the business. Nonetheless, the business is

15 Ibid, at p. 89. 
normally carried out under a trade name other than the owner's name. As sole proprietorship is not a legal entity, it has no power to hold or acquire property under its (the business) name. All assets acquired by the business belong to the owner and shall be treated as personal property.

\section{(ii) Partnerships}

A partnership is basically a business arrangement between two or more person to carry out similar nature of business with the agreement that the profits shall be shared among them. A partnership is not a legal entity and as such, the partners and the business are not distinct from one another. In fact, the firm actually represents all partners, collectively and any action against or by the firm constitutes as action of the all partners.

Although partnerships are not legal entities, the firm could hold property under its name but the property shall be held by the firm on trust for all the partners and cannot be treated as personal property of the partners. Only partnership debts could be imposed against assets of the firm and judgment debts on partners could not be imposed upon partnership property unless by way of assignment.

\section{(iii) Company}

A company is a body corporate, which entitles it to legal recognition as a legal person. The juristic personality of the company gives it certain attributes which are not available to sole proprietorships and partnerships. A company has a separate legal entity distinct from its incorporators. As a legal entity, a company has the power to acquire and own property under its name.

\section{(iv) Limited Liability Company}

Limited Liability Company (LLP) is a hybrid business entity which has attributes of both a company and a partnership. It is important to highlight that despite its name which bears the term partnerships, LLP is not a partnership and all provisions of the Partnership Act, the rules of equity and of common law applicable to partnerships, shall not be applicable 
to the LLP. The LLP has a status of a body corporate similar to a company. As such, it is recognized as a legal entity distinct from its partners and enjoys all attributes of a corporation including rights to own property.

\section{CLAIMS OF MATRIMONIAL PROPERTY IN A BUSINESS}

In Malaysia, the court generally applied the contribution test ${ }^{16}$ in deciding matrimonial property claim in business. For example, in Koay Cheng Eng v. Linda Herawati Santoso ${ }^{17}$, the respondent (wife) submitted that she is entitled to half of all the matrimonial assets, including a share in the petitioner's (husband) ENT clinic. The court held as the respondent was never involved in the setting up or management of the petitioner's ENT clinic, she was unable to prove her claim of having contributed to the clinic.

In Sivanes a/l Rajaratnam v Usha Rani a/p Subramaniam ${ }^{18}$, the Court of Appeal upheld the decision of the High Court that upon the divorce, the wife was entitled to a share of the clinic as matrimonial property because the wife had contributed to the setting up of the clinic by among others:

(i) Standing as guarantor for banking facilities;

(ii) Selling the family car to tide over the difficult period; and

(iii) Using joint savings in the opening of the clinic.

16 The contribution test highlighted that if the parties did not contribute to the business, direct or indirect or was never involved in the management of the business he or she would not be entitled to the business as part of matrimonial property. In other words, some degree of participation is required to indicate interest of the parties in the business. For further details, refer to Zuhairah Ariff Abdul Ghadas \& Norliah Ibrahim, "A Favour Fili" Ensuring the Best Interest of the Child in Determination/Division of Matrimonial Property: A Special Reference to Family Businesses, International Journal of Social Policy and Society, 2012, Vol 9, pp 27-23.

17 [2005] 1 CLJ 247.

18 [2002] 3 MLJ 273. 
Another interesting case law to highlight the approach of court in deciding interest in business as part of matrimonial property is Boto' binti Taha $v$ Jaafar bin Muhamed ${ }^{19}$ In this case the parties were married in 1966. At the time of the marriage the plaintiff-wife worked as a coffee shop assistant and the defendant-husband carried on a fishmonger business in Dungun. The business of the defendant prospered and during the marriage he bought the matrimonial home, a piece of land, 4 fishing boats, fishing nets and a fish stall. The marriage ended in a divorce in 1974 and the plaintiff applied to High Court for a declaration that she was entitled as matrimonial property to one-half share in all the properties acquired during her marriage to the defendant and to one-half of all the income derived from the properties since their divorce.

The court held that matrimonial property is based on customs practiced by the Malays and rests upon the legal recognition of the part played by a divorced spouse in the acquisition of the relevant property and in improvements done to it, in cases where it was acquired by the sole effort of one spouse only. It is due to this joint effort or joint labour that a divorced spouse is entitled to a share in the property. The fact that the plaintiff accompanied the defendant in his business trips and giving up employment because of the marriage must amount to her joint efforts in the acquisition of those properties. Interestingly, the court further held in this case that even though the plaintiff did not take direct part in the defendant's fish business, her constant companionship was responsible for the defendant's peace of mind, which enabled him to function effectively as a businessman. The evidence shows that she was helping the plaintiff's business indirectly as a partner in his business trips. As such, the properties, which are the subject of the present suit, are matrimonial property.

The above precedents highlighted that in determining right of divorced parties to claim matrimonial property in business, the courts require evidence of direct or indirect contribution of the parties in the business and some degree of participation is required to indicate interest of the parties in the business.

19 [1985] 2 MLJ 98. 


\section{BUSINESS ENTITIES AND CLAIMS OF MATRIMONIAL PROPERTY}

The interest of parties in business is normally measured in the form of ownership, i.e., the quantum of shareholding or contribution in the business. Shareholdings or ownership in business is distinct from the management right. Generally, shareholders have right to decide for the business but no right to manage the business. However, in small businesses, normally, the owners are the both the shareholders and the managers. In such as case, the owners shall have both rights to decide and manage the business. In a big business, the ownership structure and management structure are usually separated between the owners and the managers. In this circumstance, the managers only run the business but do not have the decision-making power. These two rights also depended on types of business entity of the business.

For the unincorporated business association, such as the sole proprietorships and partnerships, the ownership and management rights are not separated. The sole proprietors and partners have both powers to decide and manage the business. However, in a company structure, the decision-making is divided between the members and the directors. Members only decide during the company meetings whilst directors decide and manage the daily matters of the business. In a small company, normally the members and the directors are the same persons. In such circumstances, the members have both powers to decide and manage the business.

In discussing claims on matrimonial property in business entities, this article looks into both the pecuniary interest (business assets) and non-pecuniary interest (management and decision-making rights).

\section{(i) Business Assets}

In financial accounting, assets represent ownership of value that can be converted into cash (although cash itself is also considered an asset). ${ }^{20}$ Anything tangible or intangible that is capable of being owned or controlled to produce value and that is held to have positive economic

20 Sullivan, Arthur, Steven M. Sheffrin (2003). Economics: Principles in action. Upper Saddle River, New Jersey 07458: Pearson Prentice Hall. pp. 272. 
value is considered an asset. ${ }^{21}$ Tangible assets are those that have a physical substance and can be touched, such as currencies, buildings, real estate, vehicles, inventories, equipment and it contained various subclasses, including current assets and fixed assets. ${ }^{22}$ Intangible assets are nonphysical resources and rights that have a value to the firm because they give the firm some kind of advantage in the market place. Examples of intangible assets are goodwill, copyrights, trademarks, patents and financial assets, including such items as accounts receivable, bonds and stocks. ${ }^{23}$

It is perceived that during a marriage, the husband and wife will be accumulating assets for the household, for example houses, cars, land, shares etc. Assets which are acquired under the parties' personal name would raise less complication if claimed as matrimonial property as the court has a clear guideline on distribution of jointly acquired property as matrimonial property. However, for assets which were initially acquired by the parties under their individual names but later transferred to a business, which is owned by one or both of the divorced parties, complications may arise as to the rights of the parties in claiming the assets as a matrimonial property.

Generally, the court applied the "contribution test" in deciding rights of parties claiming for matrimonial property but this is only possible if the assets are under one of the divorced parties' name. However, once the assets have been transferred to a business, generally it shall be own by the business and the parties cannot directly claimed that the assets shall be distributed to them as matrimonial property.

One of the factors that the court needs to look at is type of business entity in which the business is carried on. If the assets were transferred to a sole proprietorship or a partnership, then there would be not much issue as the individuals still have rights upon assets of the business. This is because in both sole proprietorship and partnership's structure, the owner/partners are not distinct from the business. Any assets own by the business are deemed to be assets of the owner/ partners. However, in a company structure, once the owner transferred his or her assets to the business, it is deemed to be the company's

\footnotetext{
21 Ibid.

22 J. Downes, J.E. Goodman, "Dictionary of Finance \& Investment Terms", Baron's Financial Guides, 2003, p 285.

23 Ibid.
} 
property. In Abdul Aziz bin Atan \& 87 Ors v Ladang Rengo Malay Estate $S d n B h d,{ }^{24}$ main assets of the company consisted of land. All the shareholders of the company had transferred their entire shares to a certain buyer. A question arises as to whether assets of the company were also transferred to the buyer by virtue of sale of all the shares. The court held that it is trite law that an incorporated company is a legal person separate and distinct from the shareholders. As the company did not change its identity or personality, it continued to own all its assets. As such, if the divorced parties intend to claim that the company's assets as part of the matrimonial property, the court has to apply a different approach to determine the status of the assets prior to applying the contribution test.

The court could invoke the doctrine of lifting of the corporate veil to decide whether assets of the company could be distributed as matrimonial property. This is because only property, which belongs to the divorced parties, could be claimed and divided as matrimonial property whilst property, which has been transferred to a company, shall be considered as other person's property. However, if the court applies the doctrine of lifting of corporate veil and found that the property was transferred to the company by one of the divorced parties to avoid certain personal obligation, such as distribution of the property as a matrimonial property, the position could be different.

In Wan Khairani binti Wan Mahmood v Ismail bin Mohamad \& Anor ${ }^{25}$ the appellant and the first respondent were divorced in 1990. In 1992 the appellant commenced an action in the Syariah Court for 'harta sepencarian' orders ('the Syariah action'). The appellant and the first respondent were both directors and shareholders in the second respondent. The first respondent was the majority shareholder whereas the appellant was the minority shareholder. The appellant alleged that the first respondent was the trustee under a written trust deed dated 21 January 1986 in respect of some land ('the lands') registered in the name of the trustee and held in trust for the second respondent. The purchase price for the lands was paid for by the second respondent. The government subsequently acquired these lands and compensation monies were paid to the first respondent in 1997 and 1999. On 16 February 2001, the appellant added the lands as assets to her Syariah

\footnotetext{
24 [1985] 2 MLJ 165.

25 [2008] 1 MLJ 164.
} 
action. The Shariah court judge in this case, ${ }^{26}$ applied the doctrine of separate legal entity and lifting of corporate veil to decide whether money paid by the government for the land (claimed to be the matrimonial property) to a company, which is owned by the husband, could be claimed by the wife as matrimonial property. After detail consideration and application of the doctrine, the Shariah court judge held that there are sufficient evidence that the land belong to the company and not the husband and as such the money paid to the company for the land could not be claimed as a matrimonial property. Although in Wan Khairani case, the applicant did not succeed in her claim, the case showed that the doctrine of lifting corporate veil could be applied to decide status of assets or property, which had been transferred to a company.

The same approach was applied in Prest $v$ Petrodel Resources Limited \& $\mathrm{Ors}^{27}$ whereby upon divorced, the wife claimed her shares of the matrimonial assets in companies where husband was the majority shareholder and a director. The Supreme Court held that the husband beneficially owned the assets of the Petrodel Resources Ltd companies under a resulting trust because he contributed to their purchase price. There was no need to pierce the corporate veil, which could only be done in limited situations. However, as Mr Prest had been "entitled" to the assets of his companies under a resulting trust, under section 24 of the Matrimonial Causes Act 1973, the court had jurisdiction to transfer half the value of the properties to his ex-wife.

\section{(ii) Management rights}

In a business, the management rights refer to the right to make decision for the business. This right actually goes beyond right to profit sharing or shareholding. In a business structure, ownership and control are two distinct rights. The fact that a person holds shares or interest in the company does not necessary means that he/she has management right or control in the business. To determine the composition and distinction of ownership, the business structure/form is vital.

The decision-making power in is normally vested in the owner and the structure depends on types of business entities. For example, in

\footnotetext{
26 Case No. 0063/1991T.

27 [2013] UK SC 34.
} 
a sole proprietorship, which is a one-man business, only the owner is entitled to decide for the business. There is no issue of sharing management or decision-making rights in sole proprietorships.

On the other hand, in a partnership structure or a firm, the partnership law is clear that all partners may participate in the firm. ${ }^{28}$ This provision impliedly gives all partners the decision-making right and it is up to the partners either to be an active partner by exercising the management right or to become passive partner by not taking active role in the management of the business. In both circumstances, partners will jointly liable for the business debts..$^{29}$ No partners can be exempted from liability of the firm. This principle is known of unlimited liability. ${ }^{30}$ The unlimited liability regime, which is imposed in partnerships structure, is in fact the legal justification, which underlined the law that all partners have management rights. As such, in a partnership structure the right of participation in business is/must be shared between all partners.

In a company structure, the ownership structure is a bit more complex than sole proprietorships and partnership's structure. In a company, there are two main decision-making organs, namely the members and directors. Directors decide thought the board of directors (BOD) meeting whilst the members decide through the company's meetings (AGM or EGM). Despite the ideal perspective of giving members the right to decide in the business, the real fact is that it is the BOD that has the management right, particularly in the running of the business. ${ }^{31}$ The members' rights are only exercisable in the company's meetings and it is only if and when the company calls for a meeting, that members may exercise their decision making right other than during the AGM. If the company did not call for any meeting, members will not be able to exercise their voting rights. This highlights the fact that shareholding does not necessarily connote control. Shareholding indicates ownership but not necessarily control.

28 Partnerships Act 1961; s. 26.

29 Partnerships Act 1961; s.7 and s.11.

30 See Kasinathar Balendra Thuraisingham v. Affin Bank Berhad [2009] 1 LNS 1734; Restoran Rizqin v Asia Commercial Finance (M) Berhad \& Another Cases [2005] 1 LNS 27; MBF Capital Bhd \& Anor v. Tommy Thomas \& Anor (No 5) [1998] 3 CLJ 383.

31 Article 73; Table A, Fourth Schedule of Companies Act 1965. 
According to Dr Saleem Sheikh and Professor SK Chatterjee: ${ }^{32}$

The divergence of interest between ownership and control had created a division of functions. Within the corporation, shareholders had only interests in the enterprise while the directors had power over it. The position of the shareholders had been reduced to that of having a set of legal and factual interests in the enterprise.

As such, in a company structure, the fact that a person has bulk of shares does not automatically means that he/she has management or right to participate in the business. Another important principle to highlight is that in a company structure, the management right generally vested in the BOD, which means that it must be shared between more than one person.

One important observation, which can be highlighted, is that not all business forms allow sharing of participation rights. A divorced couple may claim certain proportion/ value of a sole proprietorships business as matrimonial property but not in right of participation as the control it vested upon one person only. On the other hand, in a partnership and a company structure, the divorced parties may claim right of participation in the business as matrimonial property because it can be shared.

\section{CONCLUSION}

In deciding claims of business interest as matrimonial property, it is important for the parties to understand the legal framework of business entities in which the business interest exist. If the business interests are in unincorporated business association, such as sole proprietorship and partnerships, it is easy to identify the interest and amount claimable by the divorced parties as the interest is vested in the name of the person. In summary, interest of a person in a partnership is in accordance of the partnership agreement whilst in a sole proprietorship all property in the

32 Dr Saleem Sheikh and Prof SK Chatterjee, Perspectives on Corporate Governance, in Dr Saleem Sheikh and Prof William Rees (eds), Corporate Governance \& Corporate Control, Cavendish Publishing Limited, London, (1995) at 40. 
business is considered property of the owner solely. However, interest of a person in a company depends merely on the shareholding that he holds in the company and all property under the company's name does not belong to any person but to the company itself. However, the doctrine of lifting of corporate veil could be applied in certain circumstances where the court is doubtful on the actual ownership of the property.

From the case law of both Syariah and civil courts, it is also observed that the civil courts require certain amount of contribution from the divorced parties in the business for a right to claim the business interest as matrimonial property whilst in the Syariah courts, the contribution test is not necessarily applied in claims of business interest as matrimonial property. 